\title{
The Struggle of Rocky to Survive in Don't Breathe Movie Directed by Fede Alvarez
}

\author{
Furi Indriyani ${ }^{1}$, Tati Mardewi ${ }^{2}$, Sharaswati Wardani ${ }^{3}$ \\ Universitas Bina Sarana Informatika \\ furi.fin@bsi.ac.id¹, tati.tdi@bsi.ac.id², sharaspanda98@gmail.com³
}

\begin{abstract}
The purpose of this study was to determine the struggle of the main character namely Rocky in Don't Breathe Movie. The writer uses the descriptive qualitative method in analyzing the struggles of the main characters in Don't Breathe Movie written by Fede Álvarez. The procedures that the writer takes to get the results are observing and understanding the movie, collecting data consisting of struggles, choosing theories to analyze data, analyzing data using theories, making conclusions from the analysis, and finally compiling the final project. The results of this study are the writer finds three types of struggle namely; struggle for life, struggle for love and, internal struggle. The struggle of life when the main character in the movie survives with full force in any situation, the struggle of love when the character in the movie has a feeling of love with other characters, the internal struggle when the character in the movie has desires and problems in her life. This movie teaches humans about how important is the struggle in life and never gives upthe main character shows people that a struggle can be motivated by certain aspects.
\end{abstract}

Keyword: Struggle, Main Character, Struggle of Life, Struggle of Love, Internal Struggle.

\section{Introduction}

Some people have opinions that literature is just a matter of fun and enjoyment. This opinion is not completely right because literature is more than just fun and enjoyment. According to Hudson (1958) "Literature is the expression of life through the medium of language. It can be considered as something essential since it contains about real life". It means that literature can be a portrait of human life because the content of literature, especially a novel, can be a description of the experience of human nature that is reflected in the language. It can be said that there is a close relationship between literature and human life. Through literature, the writer can enrich our knowledge and experiences since literature is a reflection of human life. So, reading simply doesn't enjoy the pleasure and excitement, but it candig out meaning inside because literature is the medium for learning about life.

There have been various attempts to define literature. Based on Kelley Griffith (2010) "Literature is not definable by properties, such as Rhyme, Meter, Plot, Setting, and Characterization". It assumes that the literature can be identified by 
how people use it. People use literature not to get things done but as objects of pleasure in themselves.

Based on Tabish Khair \& Sebastien Doubinsky (2011) "To understand this we have to state two obvious facts. First, literature is written in the language. Second, literature is not just about language". It means that literature is written in the language of what is capable and will not be limited to language.

A movie is a work of art in the form of moving images that are put together so that formed into a story. The movie is also an important mass communication media to provide information about the reality of life. According to Grant Horner (2010), state "Movie isperhaps the most perfect mirror. the statement shows that we haveto show ourselves what we are. But like all mirrors, the mirror of the movie is always in some sense, a distortion. The sense depends on each person to understand and know the situation.

The characters are the people in the story or the novel. The characters make up the central interest of many dramas or novels. Characters are also very important in the story, it is can make the story keep moving, without characters the story cannot be performed as a literary work. The character can be a person, animal, or anything that can represent the story flow of the movie. According to Roback Abraham Aaron (2010) "Character is gifted only for the routine in life actuated mainly by habit. The character with judgment and reason in the foreground are known for their sagacity, pursuit of the economy, and practical bent of mind." It means that character can be determined based on the habits of each individual.

Joan Chittister (2005) stated, "Struggle is part of life. In fact, the struggle is an unavoidable part of life". According to Cynthia A. Barnhart(2008) "Struggle is made great efforts with the body, try-hard, work hard, against difficulties". It means that struggle is an effort to get something against difficulties with the body, try-hard, and work hard.

According to K.M. Johnson (2009) stated: "Struggle is an exertion, strain or endeavor".The struggle is working hard to achieve our goals and sometimes there is a breakdown in the process. People just try to do their best for a better life to achieve our life goals.

From the statement above, the writer concludes acharacter in the movie is a personwho has a strong determination and struggles in her life. The struggle occurs when a human being goes through temptation and tries to get out of their own problems or a competition to get something and endeavor to get it by against difficulties and try hard until all is achieved.

The struggle is an interesting thing in character. Many characters can show their struggle in the movie. Struggle shows the extent to which characters can achieve great effort. In this paper, the writer will analyze the main character's struggle in Don't Breathe Movie. The reason is that the writer wants to know how the main character's struggle to survive. Based on the above reasons, the writer chose The Struggle of Rocky to Survive in Don't Breathe Movie Directed by Fede Alvarez as the title of the study.

\section{Research Methods}

In this paper, the writer uses a qualitative descriptive method to analyze this film, a descriptive qualitative method used by the writer in analyzing and exposing the data obtained. According to Agung(2016) "Descriptive qualitative research is

\section{ENGLISH EDUCATION}

Journal of English Teaching and Research 
one of the types of research included in this type of qualitative research. The purpose of this study is to reveal events or facts, circumstances, phenomena, variables, and circumstances that occur when the study takes place by presenting what happened. This research interprets and describes the data concerned with the current situation, attitudes, and views that occur in a society, the conflict between two or more circumstances, the relationship between variables that arise, differences between existing facts and their influence on a condition, etc."

The analytical procedure is watching and understanding the film, collecting data consisting of struggles, choosing theories to analyze data, analyzing data using theory, making the conclusion of the analysis, and the last is arranges the final assignment.

\section{Result and Discussion \\ Summary of the Story}

Rocky, Alex, and Money are three Detroit criminals who make a living by breaking into homes and stealing stuff. Rocky wanted to move to California with her youngersister, Diddy. It is because Diddy is nurtured by her mother and her alcoholic mother.

Money gets info from one of his contacts about an old man who lives in an abandoned Detroit neighborhood with more than $\$ 300,000$ in cash in his house. it was given to him as a settlement after his daughter was killed in a car accident. It was said that the man was a war veteran. He lives alone after his daughter was killed in a car accident. After some deliberation, they (Money, Alex, and Rocky) decide to break into the house at night, after stalking it out during the day and discovering that the man is in fact blind.

At night, Rocky, Alex, and Money came into the house. They found that all the entrances locked, Rocky saw that there was a window without a trellis that would fit her into the house. Rocky enters the house through the window and lets Alex and Money in. They search the house for the money but are unable to find it. They thought it must be behind a locked door. Money shoots the lock. The noise wakes up the Blind Man, who quickly disarms Money and kills him with his own gun. Rocky hides in a closet, where she sees the Blind Man open a safe to check on his money. After he leaves, Alex finds Rocky in the closet, and they open the safe and take the money, amazed to discover at least $\$ 1$ million inside. Meanwhile, the Blind Man discovers two pairs of shoes downstairs and realizes that Money was not the only intruder. There are others trapped in the house and try to get out of the house.

Rocky and Alex avoided the Blind man and entered the basement. There, they found a woman who's been chained up to the wall. the woman shows them a newspaper article. It reveals that her name is Cindy, and she's the woman who accidentally killed the Blind Man's daughter, but she was acquitted.Rocky and Alex release her and try to escape toward the cellar door. Unfortunately, the Blind Man is there when they open it. He shoots at Rocky and Alex with Money's gun but mistakenly kills Cindy instead. He weptbitterly over her body. Because Cindy was carrying his child to replace the one she killed.

Rocky and Alex rushed back to the basement while the man turned off the lights, knocking him into the dark. After a difficult struggle, Alex hits the man and they run upstairs. 
After blocking the basement door. They fled to the room, where they were trapped by a barred window. Rocky came out of the room through the ventilation duct, while the dog who woke up attacked Alex. After that, the dog chased Rocky through the vent, and she is captured by Blind Man. Rocky woke up in the basement, chained in the same spot as Cindy. She tells the Blind Man that this will not bring his daughter back. He says that is not entirely true. Cindy was carrying a child to replace for the one she killed, and he would have let her go once she gave birth. He says that Rocky must take Cindy's place.He prepares to impregnate Rocky, but luckily, Alex has gotten up and grabbed a hammer. He beats the Blind Man over the head and frees Rocky. They handcuff the man to a pole.

Rocky and Alex tried to pass the front door.However, The Blind Man reawakens, escapes his restraints, and shoots Alex, but Rocky escapes outside, pursued by the dog.Although she manages to trap the dog in her car trunk, she is captured again by the Blind Man and brought back to his house.Rocky disorients the Blind Man by setting off his house's loud alarm system, then beats him with a crowbar and pushes him into the basement. Believing he was dead, Rocky took the money and left the house before the police arrive. Rocky is now with Diddy at the Detroit airport, ready to start their new life. Rocky then sees a news report on TV, stating that the Blind Man was found aliveand killed two intruders in his house.The film ends as Rocky and Diddy leave through the departures gate.

\section{Analysis of the Story}

Don't Breathe is a 2016 American horror thriller movie directed by Fede Álvarez, and co-written by Álvarez and Rodo Sayagues. The film stars Jane Levy, Dylan Minnette, Daniel Zovatto, and Stephen Lang. The film premiered at South by Southwest on March 12, 2016, and was theatrically released on August 26, 2016, by Screen Gems and Stage 6 Films. The genre of this movie is crime, horror, and thriller. This movie is suitable for teens and adults because it contains violence. The writer is interested to analyze the story of Don't Breathe movie that discussed how the struggles appear and kinds of struggle contained in the movie. The writer found three kinds of struggle there areinternal struggle, a struggle of life and a struggle of love.

\section{Rocky's Struggle Appears in The Don't Breathe Movie}

a. When Rocky wants to take her sister away from home

Rocky, Alex, and Money are planning to rob at a blind man's house. Because Rocky needs money to take her sister away from Detroit.

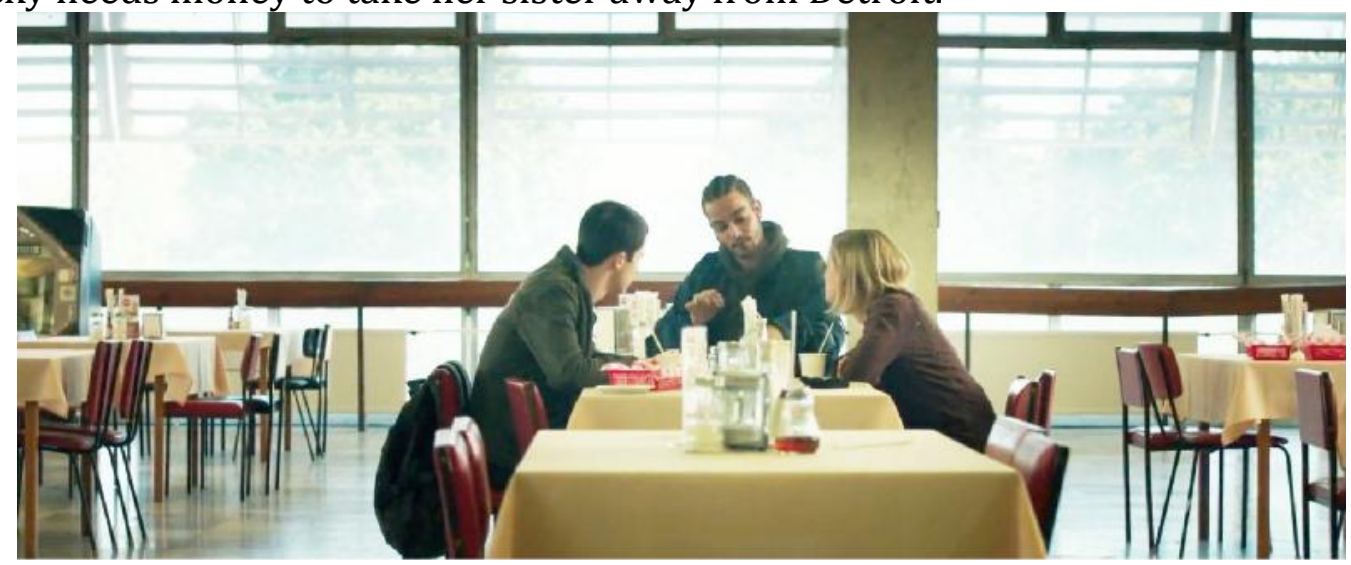

Source: Don'tBreathe Movie Directed by Fede Alvarez (06.51-08.15)

\section{ENGLISH EDUCATION}

Journal of English Teaching and Research 
Figure I

Rocky with Alex and Money

Money : "The story goes. Some preppy girl a few years ago ran over this guy's daughter. The daughter dies and his preppy rich-ass family...pays him off...gives him a big-ass settlement"

Alex : "Settlement?"

Money : "Blow me, Your Honor. All right, this guy is sitting on at least...300K. Boom. I mean, if I deliver this stake to Raul, man...he will shit his pants"

Rocky : "Do you think the money's in the house?"

Money : "I don't know. Let's go find out"

Alex : “Guys, no. we don't do cash. Above $10 \mathrm{~K}$ it's major larceny. That means 10 years if we get caught."

Rocky : "We won't get caught"

Alex : "Okay and then what? They'll do an Investigation. My dad could get in trouble"

Money : "I knew you'd bitch out man. I just knew it"

Rocky : "Alex, if we do this right, we never have to do it again. (Alex get up) Where are you going?"

Alex : "We're not doing this one". (Walk left Rocky and Money)

Rocky : "Seriously?"

Money : "Give us the fucking keys, man. We'll fucking do it

Rocky : "Alex"

(When Alex arrived at home he got a message from Rocky, which contains

“I NEED TO GET HER OUT OF HERE. PLEASE DO THIS FOR ME?')

In this scene, when Rocky gathers with Alex and Money talk about stealing money. Moneywho heard that there was a house that kept more than three thousand dollars in cash, told Alex and Rocky. Money and Rocky plan to rob the money, but Alex disagrees with the idea because of the huge amount of money and fear that his father will get into trouble if the police conduct an investigation. Not long after Alex at home, he got a message from Rocky.

Based on the picture and dialogue above, the writer concludes that Rocky will struggle to get the money after she heard from Money that there was a house that saved more than three thousand dollars in money. Rocky plans to rob the house to engage her sister away from her mother.

b. When Alex asks about Rocky's new tattoo

Alex asks about Rocky's new tattoo and she tells Alex the story of her ladybug tattoo.

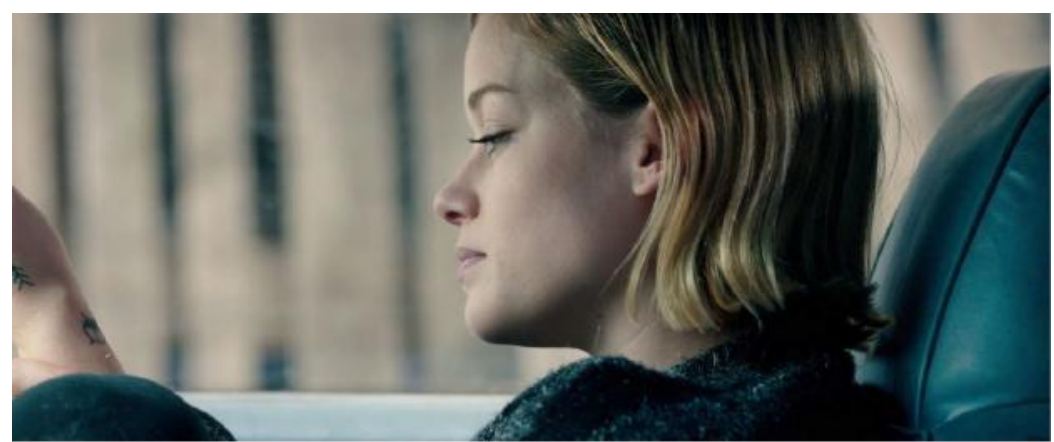

Source: Don't Breathe Movie Directed by Fede Alvarez (11.35-11.54)

Furi Indriyani, Tati Mardewi, Sharaswati Wardani |115 The Struggle of Rocky to Survive in Don't Breathe Movie Directed by Fede Alvarez 
Figure II

Rocky talked about the new tattoo

$\begin{array}{ll}\text { Alex } & \text { : "Is that a new tattoo?" } \\ \text { Rocky } & \text { : "Yeah. I got it last night" } \\ \text { Alex } & \text { : "Is that a...?" } \\ \text { Rocky } & \text { : "Ladybug" } \\ \text { Alex } & \text { : "Why ladybug?. What?" }\end{array}$

Rocky : "When my dad left, my mom started drinking. And she told me that, My dad's leaving was all my fault. And I missed him a lot, so I'd cry.she got so fed up with her crying, that she would lock me in the trunk of her car. Sometimes for hours. But there was this, um.. a little hole in the trunk and one time a ladybug flew in keep me company. It made me feel safe. When I reach California, I'm gonna color this tattoo and that's the last time I will mark my body."

Alex : "If we get this money, I'm going away with you guys."

Rocky : "I know you will."

In this scene, Alex sees a new tattoo in the hands of Rocky asking her if it is a new tattoo and why it should be ladybugs. Rocky explained to Alex about her tattoo that led to the incident in Rocky's childhood. When Rocky is crying because she missed her father and how her mother treated her rudely.

Based on the picture and dialogue above, the writer concludes that Rocky had struggled to survive even though her mother abused her since she was a child.

c. When Rocky and Alex Trapped Inside The Blind Man's House

Rocky, Alex, and Money are in the blind man's house. Money was shot by the blind man and died. Rocky saw the incident and she was very scared.

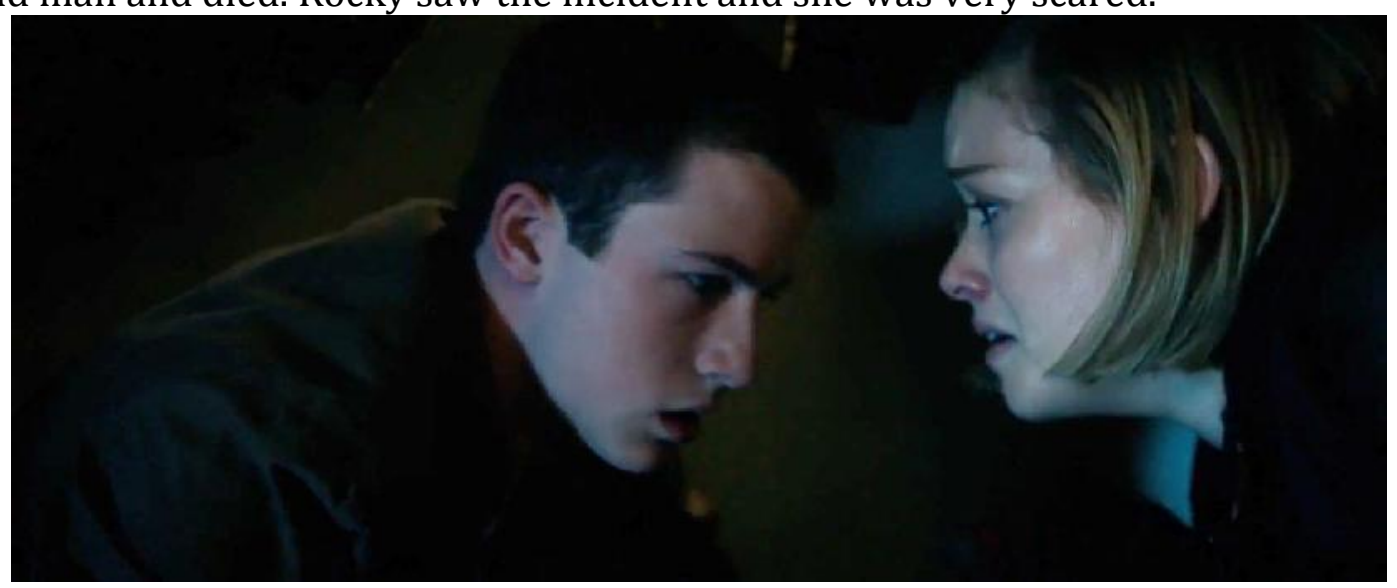

Source: Don't Breathe Movie Directed by Fede Alvarez (35.27-35.50)

Figure III

Rocky and Alex are hiding

(Alex gets a message from Rocky that says: "HE SHOT MONEY. SO SCARED PLZ HELP ME.")

Alex : "Hei Rocky are you okay? Maybe...we should call the cops before he does. We'll come clean"

Rocky : :Wait" (Rocky opened the safe and took all the money)

\section{ENGLISH EDUCATION}

Journal of English Teaching and Research 
Alex : "What? Oh, my god. There's a lot more than 300 grand in there. That's got to be a million dollars"

Rocky : "Okay, let's get out of here"

Alex : "The storm cellar door. The door's bolted from the inside. That could be our way out"

Rocky : "Let's go"

In this scene Rocky and Alex are already inside the house and hiding in the closet, Alex suggests calling the police after learning that Money was shot dead by the blind man, but Rocky asks Alex to wait and take the money. Alex is shocked by the amount of money available and they plan to get out of the blind man's house through a cellar that is connected to the door of the storm warehouse after they take the money saved by the blind man.

Based on the picture and dialogue above, the writer concludes that after Rocky saw Money being shot by the blind man and saw the password from the blind man's safe then took all the money in it. Rocky and Alex would go out of the house. Rocky struggles to takes the money and agrees with Alex's idea to leave the house through the storm cellar door.

d. When the blind man realizes that more than one person enters his house

When they arrived in the basement, they were startled by a woman chained to the wall and Alex planned to leave her.

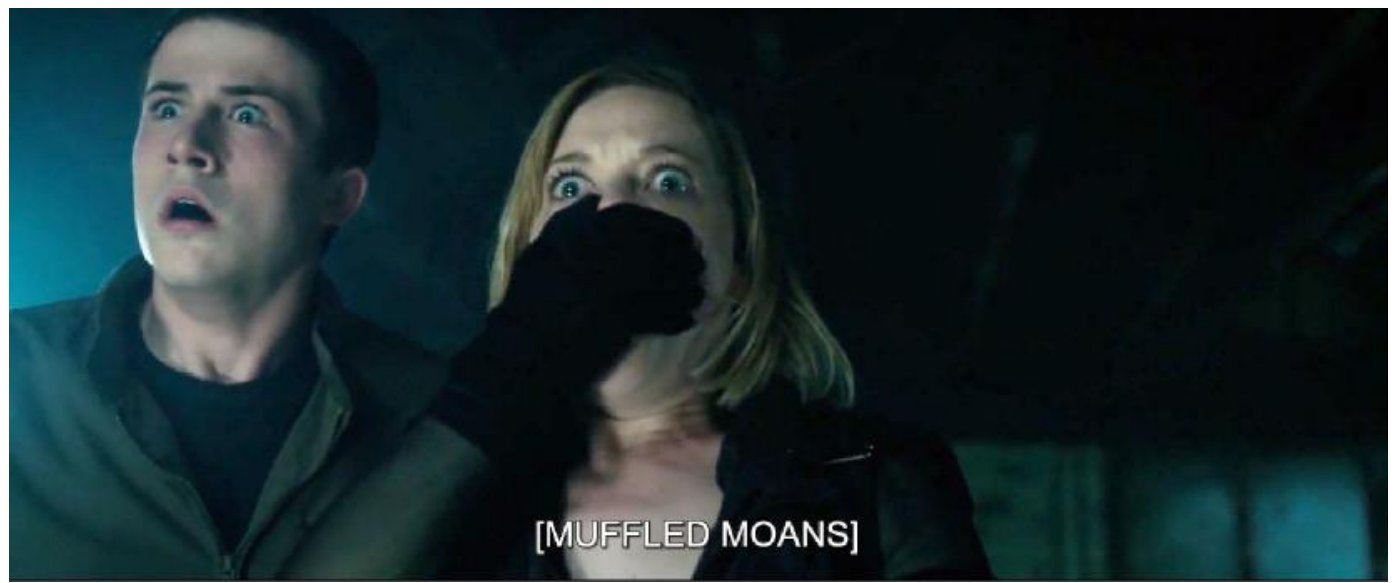

Source: Don't Breathe Movie Directed by Fede Alvarez(42.00-45.00)

Figure IV

Alex and Rocky are surprised

Alex : : "We need to get the fuck out of here right now. Come on. Let's go. Look the door's right here"

Rocky : "What?"(Rocky saw the woman holding a newspaper article and read it)

Alex : "Rocky? Rocky. Listen, listen. Hey, that's our exit. The door's right fucking there. We can leave right now"

Rocky : "She's the one who killed his daughter. We have to get her out of here"

Alex : “NO, no. Rocky, we don't have time. We'll get out of here, and call 
the cops. And then they'll come to find her, all right?. (the woman pointed at a safe not far from her) The code from the safe upstairs. You remember it?"

Rocky : "Uhmm.. 2978"

Alex : "2-9-7-8. Okay, got them" (Alex gets the key)

Rocky : :He's coming. Hurry up. (Alex manage to open the handcuffs that tied her) I don't care what you did. I'll get you out of here"

Alex : "Go!, go, go"

In this scene, Rocky and Alex who escape to the basement meet a woman who is confined by the blind man. Rocky and Alex are freaked out and almost leave her until the woman holds up a newspaper article. It reveals that her name is Cindy and that she's the woman who accidentally killed the Blind Man's daughter, but she was acquitted. Rocky and Alex free her and carry her toward the cellar door. Unfortunately, the Blind Man is there when they open it. He fires the gun and strikes Cindy in the face, killing her.

Based on the picture and dialogue above, the writer concluded that Rocky struggles to help the woman to take her out of the place.

e. When Rocky and Alex hid from the blind man in the basement

Rocky and Alex hid from the blind man in the basement. They struggle to avoid the blind man and try to get out of the house.

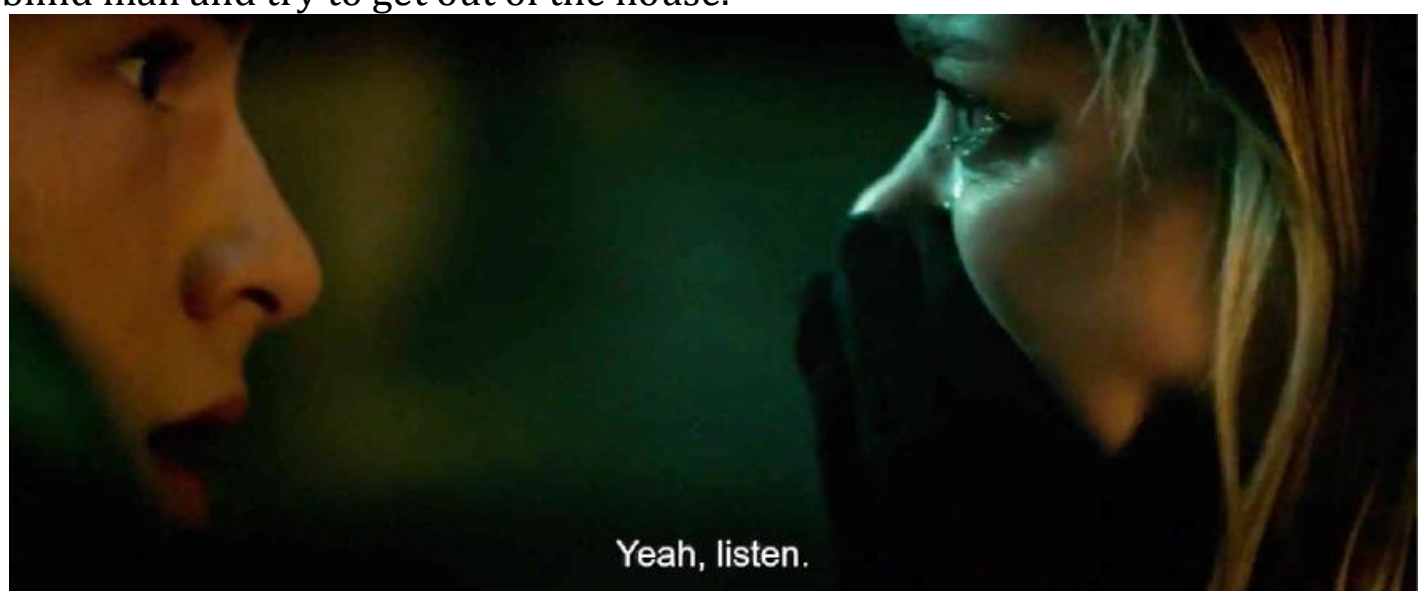

Source: Don't Breathe Movie Directed by Fede Alvarez(42.00-45.00)

Figure V

Rocky and Alex in the basement

Alex : "We have to go back upstairs. Listen, okay? These keys they match the locks on the front door, all right? If we get up there, we can get out. Okay? Let's go, now" (Alex and Rocky ran to avoid the blind man. Then The Blind Man turns off the lights in the basement)

Rocky : "Shit. Alex?" (Rocky almost touches the Blind Man until Alex calls her name)

Alex : "Rocky? (The Blind Man catches Alex and tries to shoot) Please don't. No, please.(but his gun is empty. Alex pushes a shelf down on him, trapping him). Rocky?"

Rocky : "Alex! Alex."

Alex : "Okay, let's go. Let's go. This way. This way, come on, come on, come on. Rocky,okay. Oh, come on. Where am I? Where is it? Light. I see light! Come on, come on."

\section{ENGLISH EDUCATION}

Journal of English Teaching and Research 
In this scene, Alex picks up the blind man's keys and decides to try and make it back to the front door. As he and Rocky head back upstairs, the Blind Man turns off the lights in the basement, leaving them all in total darkness. Rocky and Alex feel around for each other as the man shoots the gun. Rocky almost touches the Blind Man until Alex calls her name. The Blind Man catches Alex and tries to shoot, but his gun is empty. Alex pushes a shelf down on him, trapping him. He and Rocky run upstairs.

Based on the picture and dialogue above, the writer concludes that Rocky struggles to go upstairs to escape from the Blind Man.

f. When Rocky and Alex escape from TheBlindMan Alex and Rocky are pursued by the blind man dogs.

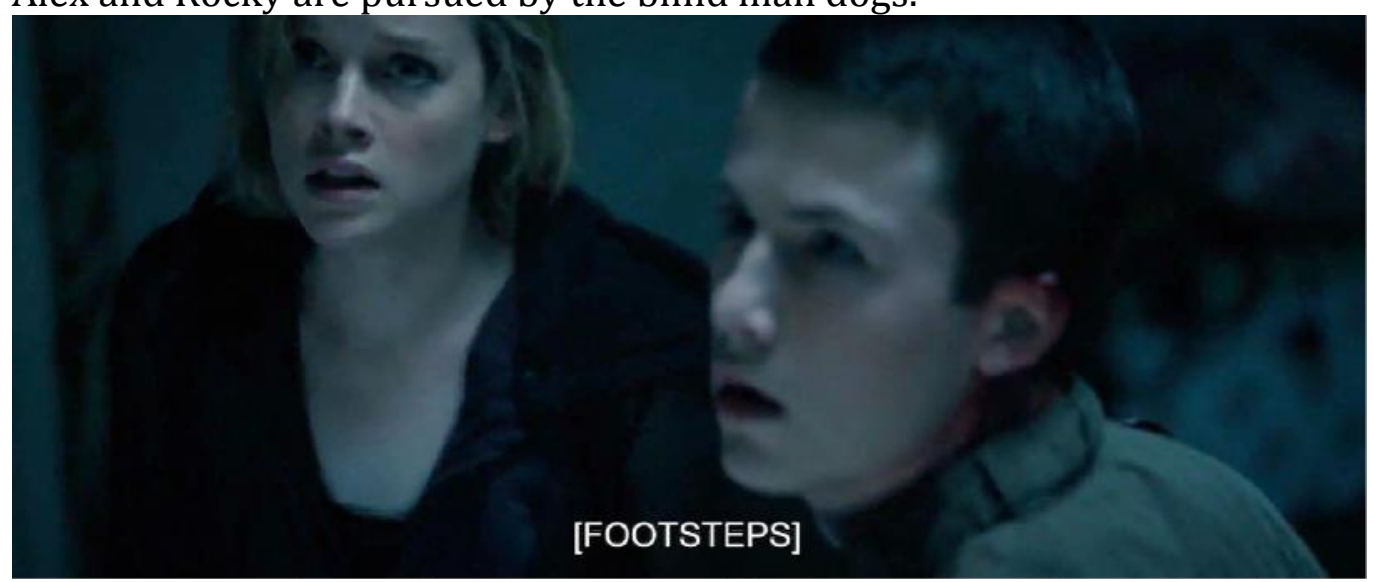

Source: Don't Breathe Movie Directed by Fede Alvarez(51.10-54.40)

Figure VI

Rocky and Alex are trapped in the room

Alex : "Rocky! Rocky. Run, now. Go, go, go! Upstairs now. Go. Go, go! Go hurry, hurry. There's a door! Come on! Let's go. Hey! Move this. (They move the cupboard to block the door) Come on. Are those blocks up too?"

Rocky : "Yeah"

Alex : "We're trapped in here. Rocky, the remote, do you have it with you? Come on," (Rocky gives the remote to Alex) "okay"

Rocky : "What are you doing?

Alex : "I'm pressing the panic button. If I manage to get in a rage, the system will call 911 and police will come"

Rocky : "No. Wait we can't go to jail"

Alex : "No. No, we won't. okay? This is robbery versus kidnapping and murder. The police won't care about us or why we were there in the first place would have helped them get this guy"

Rocky : "But then we wouldn't keep the money" (Blind man shooting at the door)

Alex : :We need to get out of this room" (Rocky pointed at the vent)

Rocky : "Up there"

Alex : "Go!"

Rocky : "Alex!” (look towards Alex) 
Alex : "What are you doing? Go!"

In this scene when Alex and Rocky run upstairs, they meet a dog of blind man who get up and are ready to attack them. They run away from dogs and unfortunately they are trapped in a room. The conversation above shows that they are indoors when blind people chase them. Alex tried to block the door, he asked Rocky to call 911 automatically with a remote system. Then he asked Rocky to escape through the air hole before the blind man caught them.

Based on the picture and dialogue above, the writer concludes that Rocky struggles to find a way out and escape from the room through the air hole.

g. When Rocky was chased by TheBlindMan dog

Rocky runs out of the blind man's house. She tries to get the car but she can not find the key.

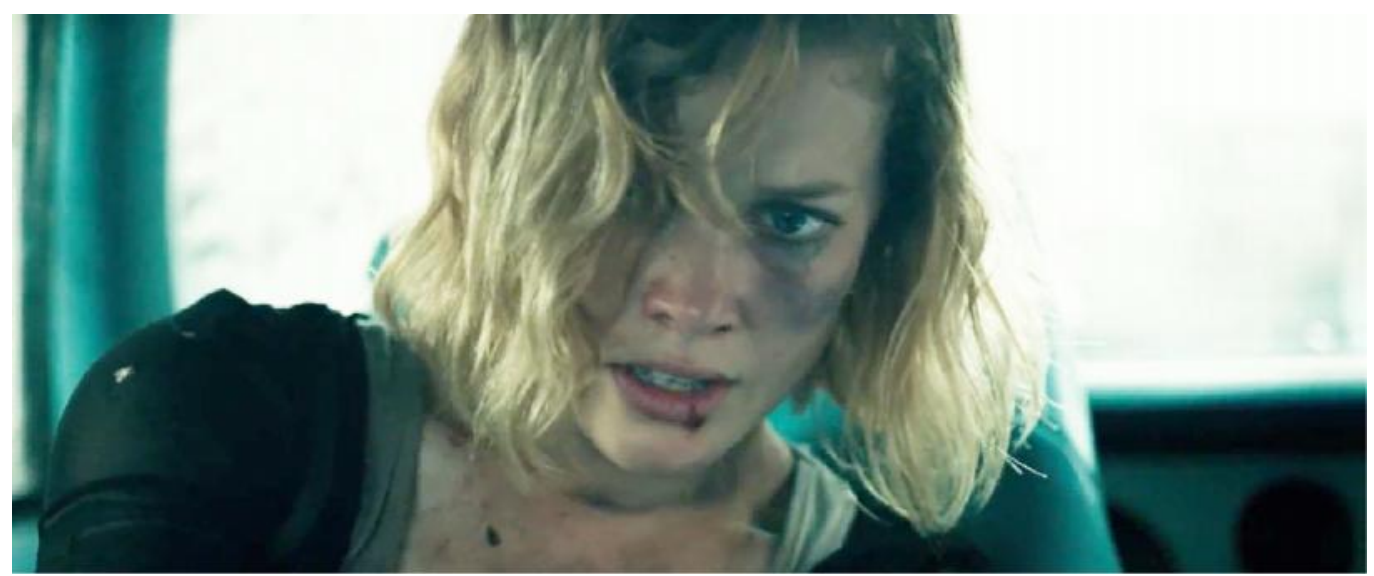

Source: Don't Breathe Movie Directed by Fede Alvarez (1.16.50-1.17.00)

Figure VII

Rocky in the car

In this scene when Rocky manages to run out of the house she is chased by the blind man dog. Rocky who ran toward the parked car, was trapped because she did not find the car key in it. While the dog is still outside watching her. Rocky is frustrated because she did not find the car key, trapping the dog into the car through the trunk so she can get out of the car through the door.

Based on the picture above, the writer concludes that Rocky struggles to find a way to escape from the dog by trapping a dog in a car

h. When Rocky is caught again by TheBlindMan

Rocky feels guilty and sorry when she sees Alex has died

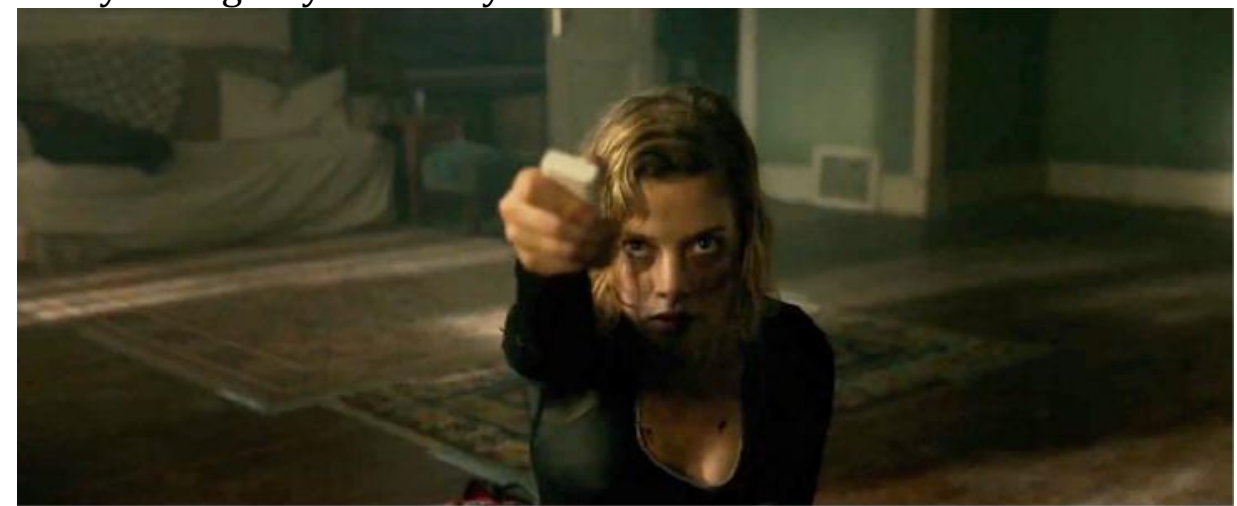

Source: Don't Breathe Movie Directed by Fede Alvarez (1.19.22-1.20.00)

120 ENGLISH EDUCATION

Journal of English Teaching and Research 
Figure VIII

Rocky pressed the alarm button

In this scene, Rocky is caught again by the blind man and sees Alex who has died feeling guilty and sorry. Then her attention was diverted towards the remote control remote then pressed the emergency call, causing the alarm to disturb the blind man. She grabbed a crowbar and hit the Blind Man in the head several times until he fell into the basement and has his gun go off, shooting him in the side. Rocky takes the money and leaves the house before the police show up.

Based on the picture above, the writer concludes that Rocky struggles to escape from the blind man and defeat him by ringing the alarm to bother him and hit him with a crowbar.

\section{RESULTS}

Struggle of Life

The analyze kinds of struggle, the writer use theory from Sam Robert (2001) "Struggle of life is when the main character in the movie or film, they survive in their life with full power in anything situation". The struggle of life that occurs in this movie is when the main character namely Rocky is trapped in the house and she is hunted by the blind man.

\section{Struggle of Love}

The analyze kinds of struggle, the writer use theory from to Hofner Stein(2004) "Struggle of love is when the character in the movie that has a love story whit others character. In the movie usually more show detail about main character whit his or her soul mate". The struggle of love that occurs in this movie is when the main character or Rocky wants to invite his sister to move from the city of Detroit to California to stay away from her sister from her mother who has a bad influence on her sister.

\section{Internal Struggle}

The analyze kinds of struggle, the writer use theory from Stephen Harrison (2012) "Internal struggle includes conflict arising within ourselves, the sources of which include our attitude, desire, choice, understanding or interpretation of life, habits, attachment to people or situations, and our expectation of how things ought to be." Based on the statement above, the internal struggle is a struggle that comes from of individual's desire and individual's problems in life.

The internal struggle occurs in this movie when the main character or Rocky has a conflict with herself and her mother. She feels sad because her mother blames her. Her mother said that her father leaving because of Rocky's fault. And her mother abuses her since she was achild.

\section{CONCLUSION AND SUGGESTION}

\section{Conclusion}

Entertainment is one that keeps people entertained and happy like watching a movie and then exploring it with an even more dramatic imagination, observers will be surprised to become a special segment. So, people can enjoy the movie but also understand the conversation in the movie. 
The struggle of life that occurs in this movie is when the main character namely Rocky is trapped in the house and she is hunted by a blind man.

The struggle of love that occurs in this movie is when the main character or Rocky wants to invite his sister to move from the city of Detroit to California to stay away from her sister from her mother who has a bad influence on her sister.

The internal struggle occurs in this movie when the main character or Rocky has a conflict with herself and her mother. She feels sad because her mother blames her. Her mother said that her father leaving because of Rocky's fault. And her mother abuses her since she was a child.

As a result of the main character's struggle, the main character shows that she can prove that she managed to get out alive from the house of the blind man and then bring his sister away from Detroit.

They give people a lot of lessons that we can take after watching this movie for example: don't underestimate others even though they have shortcomings.

\section{Suggestion}

Based on research from struggles type in Don't BreatheMovie in How to be Single movie, the writer has some suggestions as follows.

For further research, if researching struggle and the types of struggle in the movie, researchers should explain more about the types of struggles and understand them. Researchers must further understand what struggle is in the broadest sense, the struggle of life, struggle of love, and internal struggle researchers have to know about it. The writer hopes that this article can help the next researcher who wants to take the same topic.

For readers, the writer hopes this article can help the reader in understanding what is the meaning of struggle and understanding of each of the meanings of the type of struggle that has been described by researchers in this paper. The writer also hopes that readers can take positive lessons from the movie that everyone must struggle to survive in their life in a good way

\section{REFERENCES}

Agung, P. (2016). Pengertian Penelitian Deskriptif Kualitatif. Retrieved June 21, 2019, from 2016 website: https://www.linguistikid.com/2016/09/pengertian-penelitian-deskriptifkualitatif.html

Cynthia A. Barnhart. (2008). Student's Dictionary of English. New York: The Facts On File.

Grant Horner. (2010). Meaning at the Movies: Becoming a Discerning Viewer. USA: Crossway.

Hofner Stein. (2004). The Power of Struggle Character. New York: Xulon Press.

Hudson, W. H. (1958). An Introduction to The Study of Literature (George G. Harrap \& Company, Ed.). London.

Joan Chittister. (2005). Scarred by Struggle, Transformed by Hope. UK: Wm. B. Eerdmans Publishing Co.

K.M. Johnson. (2009). Knowing the Struggle is Over! USA: Xlibris Corporation.

Kelley Griffith. (2010). Writing Essays About Literature (8th ed.). USA: Wadsworth.

Roback Abraham Aaron. (2010). The Psychology of Character. London: Routledge.ge.

Sam Robert. (2001). The Struggle Definition. London Callin's Publisher.

\section{ENGLISH EDUCATION}

Journal of English Teaching and Research 
|Volume: 5 |Number: 2 |October 2020 |E-ISSN: 2503-4405 |P-ISSN: 2580-3441 |

Stephen Harrison. (2012). Appreciate The Fog: Embrace Change With Power and Purpose. Bloomington: Xlibris Corporation.

Tabish Khair \& Sebastien Doubinsky. (2011). Reading literature today. India: SAGE Publications India Pvt Ltd. 